\title{
Research and Application of BSG Motor Control Technology with a Start-stop System
}

\author{
Jiapeng $L u^{1,2, a}$, Youde $\mathrm{Li}^{2}$ and Jinghua $L v^{1}$ \\ ${ }^{1}$ FAW car Company Limited, Changchun city, Jilin Province, China \\ ${ }^{2}$ College of automobile Engineering, Jilin University, Changchun city, Jilin Province, China \\ alu_jiapeng@163.com
}

Keywords: BSG start-stop system; control strategy; examination and evaluation indicators

\begin{abstract}
BSG motor, this paper systematically presents the vehicle control principle, strategy and verification and assessment indicators of the start-stop system, and applies it successfully in a motor. Exhaust emissions and fuel-consumption tests of a vehicle were performed in the rotating hub, and the results show a 5\% reduction in fuel consumption for the motor, and a $12 \%$ decline in fuel consumption when the experiments were carried out in urban areas. The control technology and vehicle examination and evaluation indicators have important guiding significance to the subsequent research of the start-stop system.
\end{abstract}

\section{Introduction}

A BSG start-stop system belongs to a micro-hybrid technology. In other words, at the engine's idle speed, if the external environment and the vehicle status satisfy the start-stop system requirement, the engine automatically turns off when the driver releases the clutch pedal, and the engine automatically starts when the driver depresses the clutch pedal or the brake pedal[1,2]. The technology makes small changes to conventional vehicles and can significantly reduce fuel consumption, so it has become an important technology for vehicle energy conservation and emission reduction.

The vehicle control unit receives the sensor signal and the signal coming from the CAN bus, and judges whether the BSG system is working and determines whether to start or stop the engine according to the internal control strategy[3], and controls engine starting and flameout.

The vehicle control unit can control the starting and shutdown relay, thereby controlling the original vehicle ECU as well as controlling engine starting and flameout. When the vehicle control unit's shutdown relay controls the high level output, the shutdown relay switches off, the ECU power cord is disconnected, and the engine stalls. The starting gear of the original vehicle ECU ignition switch is connected to the signal line[4,5,6]. When the vehicle control unit starts, the relay control terminal has low level output, and the starting relay is closed. The starting gear of the ECU ignition switch is joined, and ECU controls the engine starting. Therefore, the vehicle control unit controls engine starting and flameout by using the relay simulation key.

\section{Vehicle Control Strategy}

The vehicle control strategy consists of three parts: the vehicle and driver safety, driving operation habits, and the environment and road adaptability. According to the abovementioned strategiese, the vehicle formulates a start-stop system control strategy, the automatic engine stopping control strategy and the automatic engine starting control strategy.

\section{Factors taken into account for developing the vehicle control strategy}

Factors regarding the vehicle and driver safety: whether the seat belt is fastened, whether the engine hood is closed, whether the BSG system is faulty, engine coolant temperature, brake system pressure after the engine is switched off, automatic vehicle sliding speed after the engine is switched off, the state of charge of a battery, and catalyst temperature, etc. 
Factors regarding driving operation habits: whether the seat belt is fastened, whether the transmission is in neutral, whether the clutch is disconnected, and whether the transmission is in reverse gear and so on.

Factors regarding the environment and road adaptability: the ambient temperature, the air conditioner application signal and automatic engine flameout when the vehicle speed is smaller than a specific value, etc.

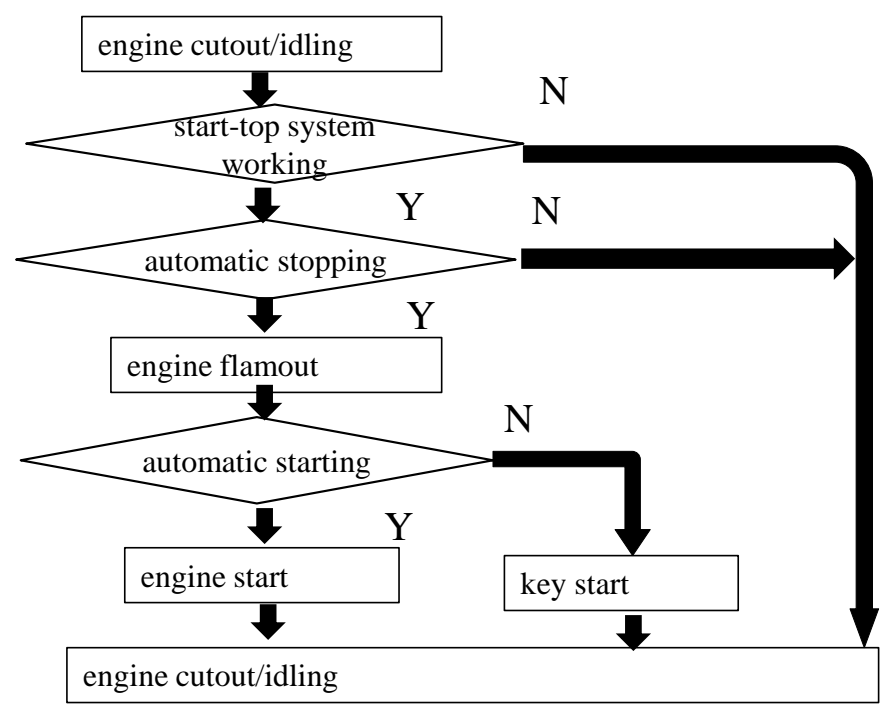

Fig. 1 The principle diagram of the vehicle control strategy

\section{The Main Content of the Vehicle Control Strategy}

\section{The Start-stop System Closing Control Strategy}

The start-stop system closing control strategy can be divided into subjective and objective levels: when the driver wants to close the start-stop system subjectively, he/she can close the start-stop system only by pressing the system closing button. If one of these conditions is met: the driver is not wearing a seatbelt, or engine hood is not closed, or the BSG system is faulty, the start-stop system automatically stops working, and the vehicle condition is the same as that without a start-stop system. The start-stop system closing control strategy is shown in Figure 2.

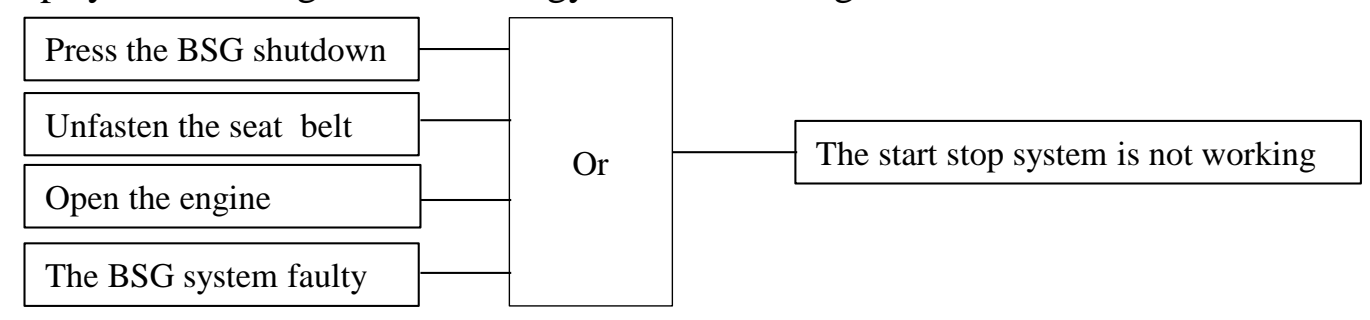

Fig. 2 The block diagram of start-stop system shutdown control

\section{The Automatic Engine Stopping Control Strategy}

When the driver encounters traffic lights or needs long-stay parking, the start-stop system can play a role and achieve automatic engine shutdown only when all of the following conditions are met. The automatic engine stoping control strategy is shown in Figure 3. 


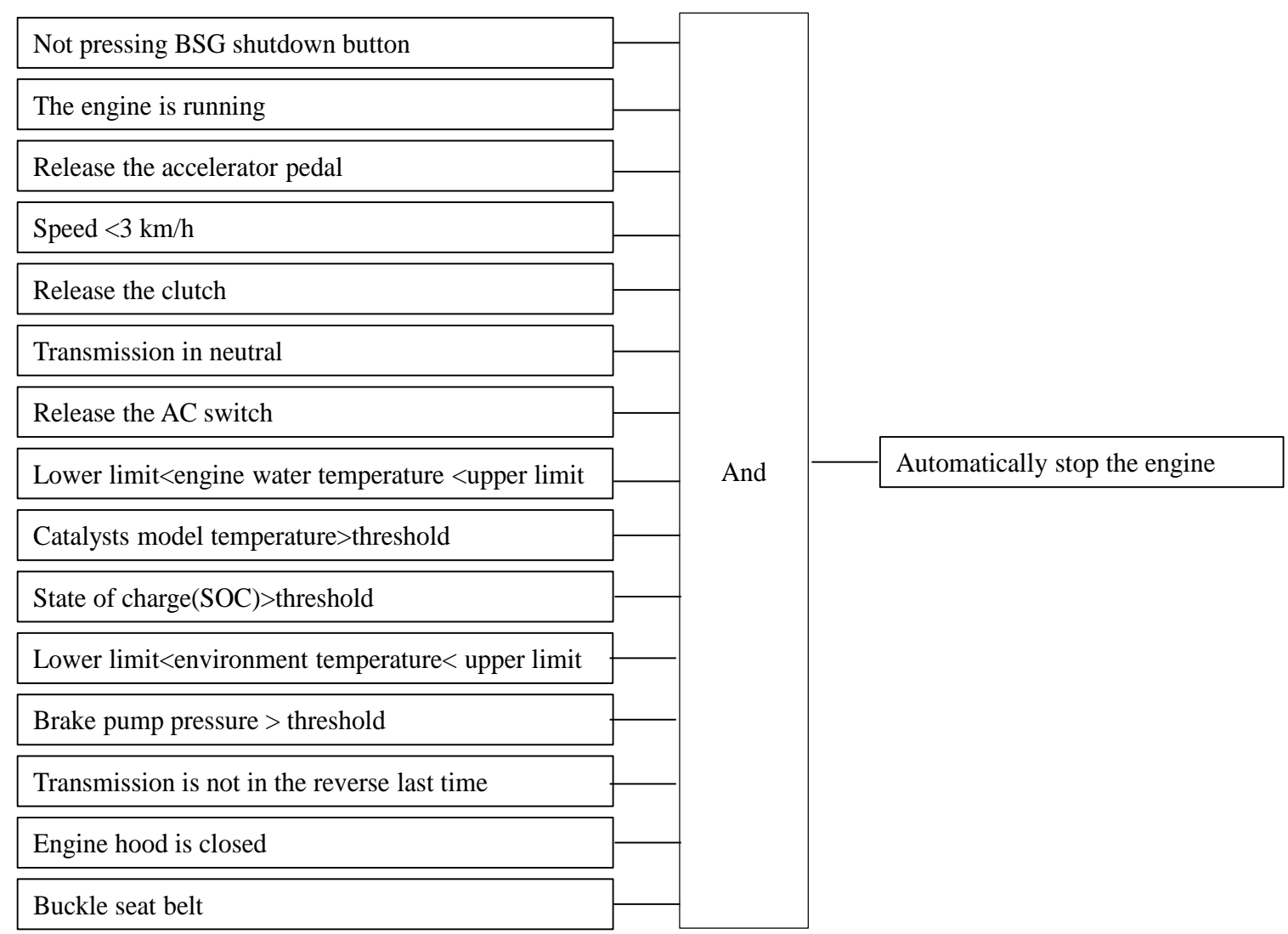

Fig. 3 The block diagram of automatic engine stopping control

\section{The Automatic Engine Starting Control Strategy}

When the driver waits for the traffic lights and needs to start the vehicle again, if one of these conditions is met: the start-stop system stops the vehicle, or engine hood is closed, or the driver is wearing a seatbelt, the start-stop system automatically starts working. The automatic engine starting control strategy is exhibited in Figure 4.

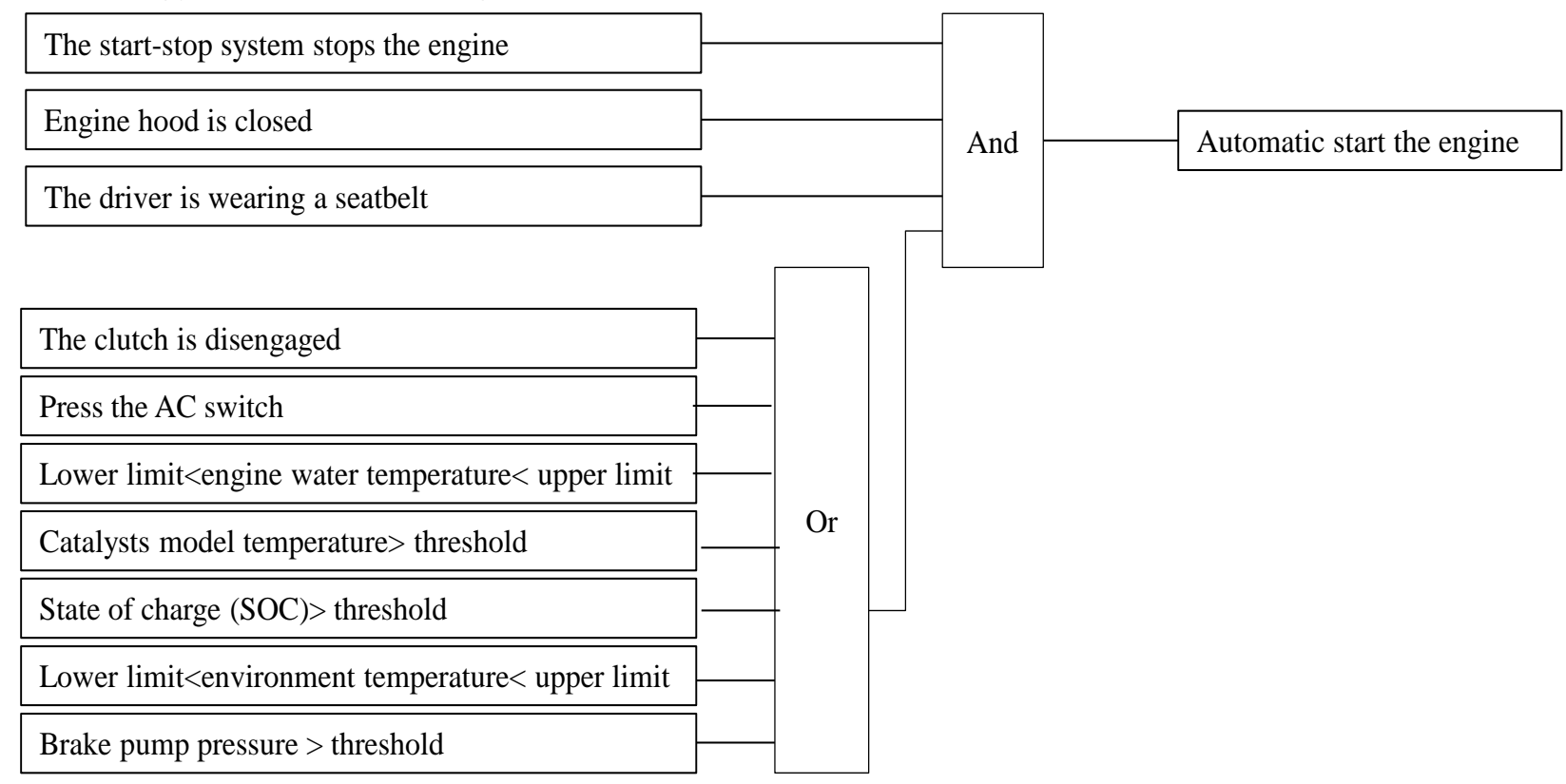

Fig. 4 The block diagram of the automatic engine starting control strategy

After the vehicle development, in order to ensure that the vehicle works stably and securely, rigorous vehicle inspection and evaluation should be carried out, including function acceptance indicators and inspection of boundary conditions. 
Vehicle Acceptance Indicators are Displayed in Table 1

Table 1 BSG vehicle acceptance

\begin{tabular}{|l|l|l|}
\hline Security and functional testing & Pass & Not pass \\
\hline Start the vehicle using the ignition key & & \\
\hline Cold start functions normally & & \\
\hline $\begin{array}{l}\text { Unlock the driver's seat belt, safety lamp } \\
\text { blinks }\end{array}$ & & \\
\hline Engine hood is open and safety lamp blinks & & \\
\hline Reverse function is operating normally & & \\
\hline Battery charge functions normally & & \\
\hline BSG shutdown switch functions normally & & \\
\hline $\begin{array}{l}\text { Automatic parking light is operating } \\
\text { normally }\end{array}$ & & \\
\hline $\begin{array}{l}\text { Automatic parking light 1Hz is flashing } \\
\text { normally }\end{array}$ & & \\
\hline $\begin{array}{l}\text { Start-stop security indicator is operating } \\
\text { normally }\end{array}$ & & \\
\hline $\begin{array}{l}\text { Start-stop security indicator 1Hz is } \\
\text { flashing normally }\end{array}$ & & \\
\hline Neutral switch is operating normally & & \\
\hline Start-stop is operating properly & & \\
\hline Start-stop system vehicle road testing & & \\
\hline $\begin{array}{l}\text { Fuel consumption test results in integrated } \\
\text { operating condition }\end{array}$ & & \\
\hline Cold start testing results & & \\
\hline
\end{tabular}

Vehicle Boundary Testing is Shown in Table 2.

Table 2 Vehicle boundary conditions test

\begin{tabular}{|l|l|l|l|}
\hline \multicolumn{4}{|c}{ Automatic stopping boundary conditions } \\
\hline Boundary conditions & $\begin{array}{l}\text { Calibrata } \\
\text { ble }\end{array}$ & Boundaries & $\begin{array}{l}\text { Current } \\
\text { settings }\end{array}$ \\
\hline $\begin{array}{l}\text { Minimum cooling water } \\
\text { temperature limit }\end{array}$ & Yes & $-40-140^{\circ} \mathrm{C}$ & $>21^{\circ} \mathrm{C}$ \\
\hline $\begin{array}{l}\text { Vehicle activating start-stop } \\
\text { function }\end{array}$ & Yes & $-40-140^{\circ} \mathrm{C}$ & $<110^{\circ} \mathrm{C}$ \\
\hline $\begin{array}{l}\text { Activation speed for automatic } \\
\text { start-stop function }\end{array}$ & Yes & $0-140 \mathrm{~km} / \mathrm{h}$ & $>6 \mathrm{~km} / \mathrm{h}$ \\
\hline $\begin{array}{l}\text { Maximum road speed for } \\
\text { automatic stopping }\end{array}$ & Yes & $0-140 \mathrm{~km} / \mathrm{h}$ & $<2 \mathrm{~km} / \mathrm{h}$ \\
\hline $\begin{array}{l}\text { Outside temperature exceeds a } \\
\text { value }\end{array}$ & Yes & $-40-140^{\circ} \mathrm{C}$ & $>-10^{\circ} \mathrm{C}$ \\
\hline $\begin{array}{l}\text { Air conditioning starts and } \\
\text { outside temperature is low }\end{array}$ & Yes & $-40-140^{\circ} \mathrm{C}$ & $<35^{\circ} \mathrm{C}$ \\
\hline Engine hood is closed & $\begin{array}{l}\text { No, } \\
\text { switch }\end{array}$ & $\begin{array}{l}\text { Start-stop system works, } \\
\text { must be closed }\end{array}$ & Activation \\
\hline Fasten seat belt & $\begin{array}{l}\text { No, } \\
\text { switch }\end{array}$ & $\begin{array}{l}\text { Start-stop system works, } \\
\text { must be fastened }\end{array}$ & Activation \\
\hline Neutral selection & $\begin{array}{l}\text { No, } \\
\text { switch }\end{array}$ & $\begin{array}{l}\text { Start-stop system works, } \\
\text { must be in neutral }\end{array}$ & Activation \\
\hline The last choice is forward gear & No, use & Start-stop system works, & Activation \\
\hline
\end{tabular}




\begin{tabular}{|c|c|c|c|}
\hline & $\begin{array}{l}\text { the } \\
\text { reverse } \\
\text { switch }\end{array}$ & $\begin{array}{l}\text { the last choice must be } \\
\text { forward gear }\end{array}$ & \\
\hline The start-stop system enabling & $\begin{array}{l}\text { No, } \\
\text { switch }\end{array}$ & Chosen by the driver & Activation \\
\hline Trouble-free code & $\begin{array}{l}\text { No, } \\
\text { switch }\end{array}$ & Trouble-free is activated & Activation \\
\hline $\begin{array}{l}\text { Catalyst temperature exceeds a } \\
\text { value }\end{array}$ & Yes & $-50-1000^{\circ} \mathrm{C}$ & $138^{\circ} \mathrm{C}$ \\
\hline $\begin{array}{l}\text { Vehicle stops automatically } \\
\text { when battery SOC is less than a } \\
\text { certain value }\end{array}$ & Yes & $0-100 \%$ & $<40 \%$ \\
\hline The engine is in the idle state & Yes & 0-7000rpm & $<1400 \mathrm{rpm}$ \\
\hline $\begin{array}{l}\text { Brake pump pressure is larger } \\
\text { than a value }\end{array}$ & Yes & 0-100kpa & $>10 \mathrm{kpa}$ \\
\hline \multicolumn{4}{|c|}{ Normal starting boundary conditions } \\
\hline Engine hood is closed & $\begin{array}{l}\text { No, } \\
\text { switch }\end{array}$ & $\begin{array}{l}\text { Start-stop system works, } \\
\text { must be closed }\end{array}$ & Activation \\
\hline Fasten seat belt & $\begin{array}{l}\text { No, } \\
\text { switch }\end{array}$ & $\begin{array}{l}\text { Start-stop system works, } \\
\text { must be fastened }\end{array}$ & Activation \\
\hline Neutral selection & $\begin{array}{l}\text { No, } \\
\text { switch }\end{array}$ & $\begin{array}{l}\text { Start-stop system works, } \\
\text { must be in neutral }\end{array}$ & Activation \\
\hline Release/depress the clutch & $\begin{array}{l}\text { No, } \\
\text { switch }\end{array}$ & $\begin{array}{l}\text { The driver depresses the } \\
\text { clutch and starts the } \\
\text { engine }\end{array}$ & Activation \\
\hline The start-stop system enabling & $\begin{array}{l}\text { No, } \\
\text { switch }\end{array}$ & Chosen by the driver & Activation \\
\hline Trouble-free code & $\begin{array}{l}\text { No, } \\
\text { switch }\end{array}$ & Trouble-free is activated & Activation \\
\hline \multicolumn{4}{|c|}{ Automatic starting boundary conditions } \\
\hline Engine hood is closed & $\begin{array}{l}\text { No, } \\
\text { switch }\end{array}$ & $\begin{array}{l}\text { Start-stop system works, } \\
\text { must be closed }\end{array}$ & Activation \\
\hline Fasten seat belt & $\begin{array}{l}\text { No, } \\
\text { switch }\end{array}$ & $\begin{array}{l}\text { Start-stop system works, } \\
\text { must be fastened }\end{array}$ & Activation \\
\hline Neutral selection & $\begin{array}{l}\text { No, } \\
\text { switch }\end{array}$ & $\begin{array}{l}\text { Start-stop system works, } \\
\text { must be in neutral }\end{array}$ & Activation \\
\hline Release/depress the clutch & $\begin{array}{l}\text { No, } \\
\text { switch }\end{array}$ & Trouble-free is activated & Activation \\
\hline The start-stop system enabling & $\begin{array}{l}\text { No, } \\
\text { switch }\end{array}$ & Chosen by the driver & Activation \\
\hline \multicolumn{4}{|c|}{ Automatic starting -Meet the above conditions and meet any of the conditions below } \\
\hline $\begin{array}{l}\text { Vehicle stops automatically } \\
\text { when battery SOC is less than a } \\
\text { certain value }\end{array}$ & Yes & $0-100 \%$ & $<30 \%$ \\
\hline $\begin{array}{l}\text { The minimum speed to } \\
\text { automatically activate start } \\
\text { function }\end{array}$ & Yes & $0-140 \mathrm{~km} / \mathrm{h}$ & $>6 \mathrm{~km} / \mathrm{h}$ \\
\hline $\begin{array}{l}\text { Brake pump pressure is larger } \\
\text { than a value }\end{array}$ & Yes & 0-100kpa & $>10 \mathrm{kpa}$ \\
\hline $\begin{array}{l}\text { The ignition key is turned to the } \\
\text { starting position }\end{array}$ & $\begin{array}{l}\text { No, } \\
\text { switch }\end{array}$ & No & No \\
\hline
\end{tabular}




\section{Conclusion}

A start-stop vehicle is developed in accordance with the BSG start-stop vehicle control strategy proposed in this paper, and the aforementioned vehicle examination and evaluation test indicators are used for evaluation, and the vehicle design satisfies the requirements. Exhaust emissions and fuel-consumption tests of a vehicle with a BSG start-stop system were performed in the rotating hub, and the results show a $5 \%$ reduction in fuel consumption for the motor, and a $12 \%$ decline in fuel consumption when the experiments were carried out in urban areas.

\section{References}

[1] Peraldi-Frati, M. A., Goknil, A., Adedjouma, M., \& Gueguen, P. Y. Modeling a bsg-e automotive system with the timing augmented description language. Leveraging Applications of Formal Methods, Verification and Validation. Applications and Case Studies. Springer Berlin Heidelberg, (2012) 111-125.

[2] Dan D, Weijun Z. Nitrogen gas generation car coiled tubing gas lift drainage technology in the application of Sulige gas field. Petrochemical Industry Application, (2012), 9: 027.

[3] Wakeham K J, Rideout D G. Model complexity requirements in design of half car active suspension controllers[C]//ASME 2011 Dynamic Systems and Control Conference and Bath/ASME Symposium on Fluid Power and Motion Control. American Society of Mechanical Engineers, (2011) 839-846.

[4] Gautam D, Goel L, Ayyanar R, et al. Control strategy to mitigate the impact of reduced inertia due to doubly fed induction generators on large power systems. Power Systems, IEEE Transactions on, 2011, 26(1), 214-224.

[5] Roh J, Chung W. Reversing control of a car with a trailer using a Driver Assistance System[C]//Advanced Robotics and its Social Impacts (ARSO), 2010 IEEE Workshop on. IEEE, (2010) 99-104.

[6] He R, Liu C, Li N. Fuzzy control of the integrated system of electromagnetic brake and friction brake of car. Jixie Gongcheng Xuebao(Chinese Journal of Mechanical Engineering), 2010, 46(24), 83-87. 